\title{
A Collaborative Approach to Retention Between Academic Affairs and Student Affairs: The Two Consecutive Absence Policy
}

\author{
Stuart Brown, Director of Student Services \\ Jamie Caruso, Director of Special Programs \\ Bette Ellis, Registrar \\ The University of Connecticut \\ Waterbury Regional Campus, USA
}

\begin{abstract}
Retention of college students has been increasingly important for institutions of higher education as costs rise and incoming students lack the necessary preparation for the academic rigour they face. Addressing this issue is not simply the domain of academic affairs or student affairs. To be successful, a school's retention efforts need to be collaborative between the two divisions. The "Two Consecutive Absence Policy," described in this article, is an example from a North American university of a unique and successful collaborative effort between academic affairs and student affairs to reach out to undergraduates experiencing academic difficulty in order to increase the campus' retention numbers. The program, briefly outlined here, can easily be replicated at other colleges or universities.
\end{abstract}

Keywords: retention, academic probation, collaboration

\section{Introduction}

Colleges and universities understand that assisting undergraduates on academic probation is critical for retaining students (Preuss and Switalski, 2008). However, according to Bridget Burns, executive director of the University Innovation Alliance, "traditionally...students [are] allowed to carry on, when immediate intervention [is] needed. Usually schools intervene when they are too far gone." (NY Times, June 7, 2017). Passive methods such as sending warning letters to students on academic probation have not been successful (Moss and Yeaton, 2015). Schools that have been more direct and intrusive with their programs have seen positive results (Cholewa and Ramaswami, 2015). These include "significant increases in the likelihood that students on probation would avoid suspension, would improve their GPA, and would remain enrolled in their classes at the college." (Preuss and Switalski, 2008, p. 2).

\section{Implementation of Retention Program}

In order to better respond to the needs of students on academic probation, the Waterbury Regional Campus of the University of Connecticut in the United States of America (USA) enacted a Two Consecutive Absence Policy. The idea, proposed by the campus Retention Committee, was created to connect with students missing classes and to provide support to prevent them from potentially failing one or more classes, being placed on scholastic probation, or being academically dismissed from the University.

Staff and administration in Student Affairs partnered with Academic Affairs to implement the Two Consecutive Absence Policy. This type of collaboration has been cited as being critically important for student success (Banta \& Kuh, 1988, Kuh, 1996; Kellogg, 1999; Kezar, Hirsch, and Burack, 2002). Trudy W. Banta and George D. Kuh are more blunt. They state, "improving the quality of the undergraduate experience at any institution is so complex and multifaceted that it demands cooperation by the two groups on campus that spend the most time with students: faculty members and student affairs professionals." (Banta \& Kuh, 1998, p. 42).

At the start of each semester all faculty receive an email stating the policy and encouraging them to 
participate. The email is as follows:

From the Waterbury Campus Retention Committee...

Students at risk of doing poorly in their classes are of concern to the Waterbury campus as a whole. Therefore, the Waterbury Campus Retention Committee urges you as a faculty member to forward the name of any student who has missed two consecutive classes to Bette Ellis, Registrar [Bette.Ellis@uconn.edu], so that she, in concertwith Dr. Stuart Brown, Director of Student Services and Jamie Caruso, Director of Special Programs, may make the appropriate inquiries into the student's status. The committee's belief is that such inquiries are in the best interests of the student and the Waterbury campus, particularly if those absences are addressed in a timely manner.

If students miss two consecutive classes, the faculty forwards the names of the students to our Registrar, Bette Ellis. Ms. Ellis forwards those names to Dr. Brown and Jamie Caruso. Dr. Brown keeps a spreadsheet with the student's names, class(es) missed, instructor, date the absence is reported, and action taken. Working as a team, the determination is made how best to contact the student, usually by email or phone. If, after several attempts, there is no response, a written letter is sent to the student's mailing address or a follow-up phone call is made or email sent. During this process Dr. Brown and Ms. Caruso are in continuous contact with the student's faculty member. The two also meet weekly to discuss and update the status of the student on the spreadsheet.

Once contact is made, the staff member seeks to understand the reason for the absences and to identify academic needs and/or personal issues. Students are advised to connect with their faculty for missed lectures and assignments should the student decide to continue with the course. Sometimes the issue(s) could be as simple as an illness. Often, though, there are more substantial reasons. Based on the circumstances, the staff may refer the student to campus resources such as Tutoring, the Office of Financial Aid, or to the campus personal counsellor. In some cases a course withdrawal or a complete withdrawal from the University is recommended.

Example: A Spring 2017 student missed two consecutive English classes at the start of the semester. The instructor notified Bette Ellis, who referred the student to Dr. Brown and Ms. Caruso. Ms. Caruso met with the student four times; referring him to the Writing Center, the Study and Life Skills Tutor, and back to the faculty. Keeping in regular contact with the student, Ms. Caruso met with the student just prior to the course withdrawal deadline and advised him to drop the course. The withdrawal put the student in Good Standing at the end of the semester, preventing him from being academically dismissed from the University.

\section{Conclusion}

The Two Consecutive Absence Policy has had a direct impact on the number of students on probation and on the semester ending dismissal list. The number of students on probation has consistently dropped while the retention rate has consistently risen. In Spring 2017 there were only five students up for dismissal, the lowest number to date in recent memory. Below are retention statistics for students on probation from the last three semesters:

$\begin{array}{llll}\text { Spring 2016: } & 52 \text { students on probation } & 37 \text { retained } & (71 \%) \\ \text { Fall 2016: } & 46 \text { students on probation } & 36 \text { retained } & (78 \%) \\ \text { Spring 2017: } & 39 \text { students on probation } & 34 \text { retained } & (87 \%)\end{array}$

Another way to evaluate the Two Consecutive Absence Policy is to compare the number of students who were eligible for academic dismissal after Spring 2017 with the other three regional University of Connecticut campuses. 


\section{Campus Est. \#}

Avery Point

Hartford

Stamford

Waterbury
Students \#

598

1045

1252

699
Eligible for Dismissal

19

49

29

5

Based on the percentage of undergraduates at the four regional campuses the number of students who were eligible for academic dismissal at the Waterbury Campus was much lower then at any of the other campuses.

The Two Consecutive Absence Policy has been an important strategy of the retention efforts at the University of Connecticut at Waterbury. It has helped the campus be successful in connecting with students, offering guidance, and supporting their decisions in achieving their academic goals. 


\section{References}

Banta, T. W. \& Kuh, G. D. (1998). A missing link in assessment: collaboration between academic and student affairs professionals. Change, 30(2), 40-46.

Cholewa, B. \& Ramaswami, S. (2015). The effects of counseling on the retention and academic performance of underprepared freshmen. Journal of College Student Retention: Research, Theory \& Practice, 17(2), $204-225$.

Kellogg, K. (1999). Collaboration: Student affairs and academic affairs working together to promote student learning. ERIC Clearinghouse on Higher Education. Retrieved from http://files.eric.ed.gov/fulltext/ED432940.pdf

Kezar, A., Hirsch, D. J., \& Burack C. (2001). Understanding the role of academic and student affairs collaboration in creating a successful learning environment. San Francisco, CA: Jossey-Bass.

Kuh, G. D. (1996). Guiding principles for creating seamless learning environments for undergraduates. Journal of College Student Development, 37(2), 35-48.

Moss, B. \& Yeaton, W. (2015). Failed warnings: Evaluating the impact of academic probation warning letters on student achievement. Education Review, 39(5), 501-524.

Preuss, M. \& Switalski, R. (2008). Academic probation intervention through academic assistance advising. ERIC Clearinghouse on Higher Education, 2008. Retrieved from http://files.eric.ed.gov/fulltext/ED502891.pdf

Steinhauer, J. (2017). The telltale data that can identify college students at risk. The New York Times. Retrieved from https://www.nytimes.com/2017/06/07/education/at-risk-college-students-early-intervention.html

The authors may be contacted via:

stuart.brown@uconn.edu

\section{Please cite this article as:}

Brown, S., Caruso, J. \& Ellis, B. (2018). A Collaborative approach to retention between Academic Affairs and Student Affairs: The two consecutive absence policy. Journal of the Australian and New Zealand Student Services Association, (26)1, 60-63. https://doi.org.10.30688/janzssa.2018.06 